\title{
Investigation on sand-dune afforestation by Eucalyptus (Eucalyptus grandis W. Hill) in Patara-Antalya region
}

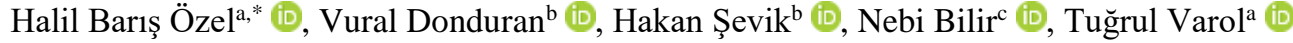

\begin{abstract}
As a result of the measurements made in these afforestation works carried out with the Eucalyptus (Eucalyptus grandis W. Hill) species under the scope of Patara Sand-Dune Afforestation Works in Kas district of Antalya province, the average breast height growth was found to be between 32.4 and $46.5 \mathrm{~cm}$, the average height growth was found to be between 15.2 and $24.6 \mathrm{~m}$ and the average growing stock per hectare was found be varying between 9.164 and $17.098 \mathrm{~m}^{3} / \mathrm{ha}$. Moreover, it was found that outstanding results had been achieved with this sand-dune afforestation work carried out to prevent the threat of the sand-dune movements to the inner settlements and fertile agricultural lands, and that new fertile soil formations had been obtained. In addition to this, although the Eucalyptus species used in afforestation was an exotic species, it was also determined that the average adaptability varied between 71.8 and $86.3 \%$ and that it showed a great adaptation to the region.

Key words: Sand-dune afforestation, eucalyptus, diameter, height, adaptability
\end{abstract}

\section{Introduction}

The future of world's forests, which have contributed to humanity significantly since geologic times with the products they provide and the functions they perform, is considerably threatened by the effects of many biotic and abiotic hazards, especially global warming. Within this context, maintaining the continuity of forests playing an active role in reducing carbon emissions, which is one of the most important causes of global climate change threatening the public health and the life of all living creatures today, depends on successful technical interventions and afforestation works. Especially, by non-forest lands gaining forest qualities as a result of afforestation works to be carried out in those lands, the production and functional values will increase as well as the contribution to national economy.

According to the statements made by the Food and Agriculture Organization (FAO), taking all the reasons within the last 50 years into consideration, approximately $43.7 \%$ of the world's forests from the equator to the poles have completely lost their forest quality and thus have become degraded forests (FAO 2019). In addition to this, as a result of wild-fires occurred in both European and Asian countries and the continent of Australia in 2019, a total of 11 million ha of forest land was lost irreversibly (FAO 2019).

Despite having approximately 23 million ha forest lands in our country, $50 \%$ of our forest assets either have low yield strength or are destructed as a result of forest fires, open mining operations and overproduction practices occurred in 2018, 2019 and 2020 (Anonymous 2019).
Therefore, in order to ensure a sustainable management of both benefits and services provided from forests also in our country, it is necessary to make degraded forest lands productive again by reforestation and to gain new forest lands through important technical applications to be carried out, arid land afforestation and sand-dune afforestation works.

Within the scope of this study, the growth status and adaptation ability is determined of used by Eucalyptus in the sand-dune afforestation established in Patara sanddune area in 1933.

\section{Materila and methods}

\subsection{Material}

Patara sand-dune afforestation came into operation on the date of 24.12.1938 after the seedlings located in the nursery field in Cirkinoba, Antalya were transferred to Karagol swamp in Kalkan upon approval dated 24.11.1937 and numbered 2307 of Ministry of Agriculture by being the observer of the Eucalyptus afforestation of Kalkan Karagol swamp (Kalkan Ovagelemis Eucalyptus Nursery and Afforestation). While it was operating as a nursery and afforestation subdirectorate affiliated with the Forestry Operation Directorate of Kas at first, later it became affiliated to the Forestry Operation Directorate of Elmali and then to the Forestry Operation Directorate of Kas again (Anonymous 1938). The land, which was considered by the forest administration for afforestation, belonged to the state treasury and its title deed was registered on the a Department of Forest Engineering, Faculty of Forestry, Bartin University, Bartin

b Department of Environmental Engineering, Faculty of Engineering and Architecture, KastamonuUniversity, Kastamonu

c Department of Forest Engineering, Faculty of Forestry, Isparta University of Applied Sciences, Isparta

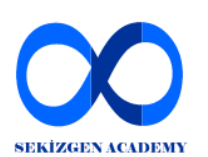

Citation: Özel H.B, Donduran V, Şevik H, Bilir N, Varol T (2021). Investigation on sand-dune afforestation by Eucalyptus (Eucalyptus grandis W. Hill) in Patara-Antalya region. Theoretical and Applied Forestry 1: 34-39.

doi: 10.53463/tafor.2021vol1iss1pp34-39 
forest administration. According to this title deed, the size of land was 400 hectares and according to the map made by the eucalyptus afforestation sub-directorate, the breadth of only a part of it was found to be 329.5 hectares. In its current title deed, it is registered in the land registry as a eucalyptus state forest with an area of $5,187,574.69 \mathrm{~m}^{2}$ (518.8 hectares) in Ova/Yesilyurt neighbourhood, Karagol location with the lot no. 176 and the parcel no. 1 . In afforestation, $3 \times 3 \mathrm{~m}$ was used as planting distance. In the research area, granular and locally cubic structure at sand-clay texture is dominant, the wind blows from the west, the average temperature is $19.2{ }^{\circ} \mathrm{C}$ and the average precipitation is around $743 \mathrm{~mm}$ (Anonymous 2018) (Figures 1, 2 and 3). Also, the research area is facing south and southwest, and the elevation is $5 \mathrm{~m}$.

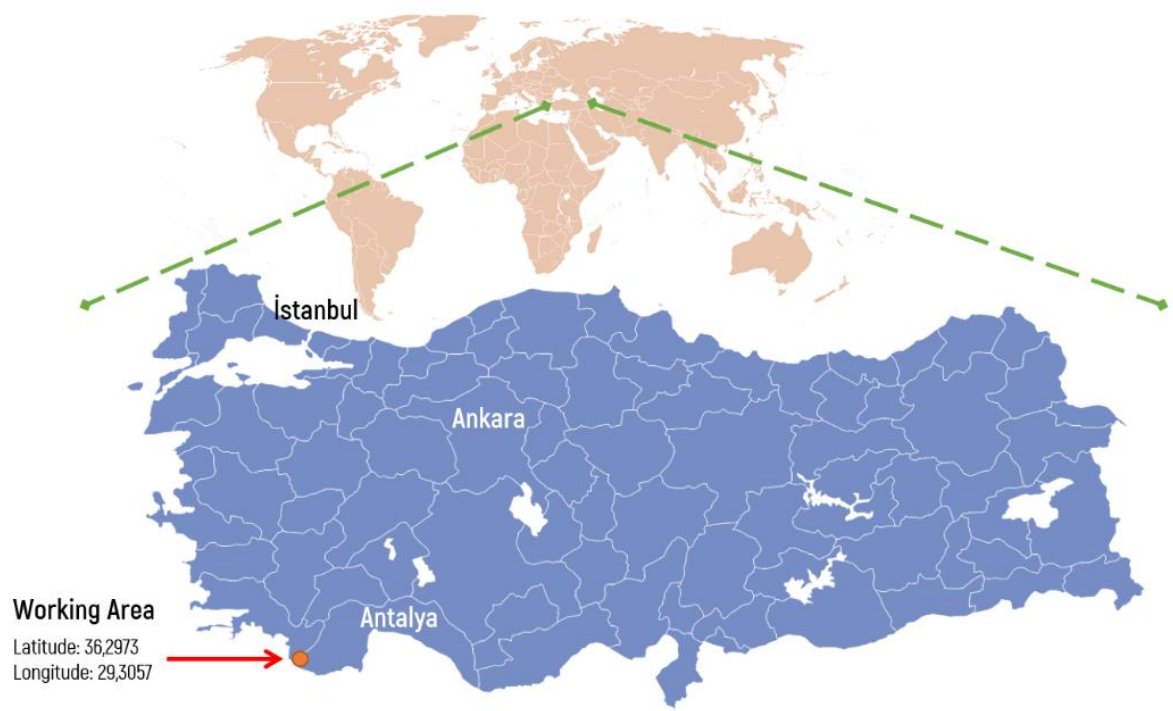

Figure 1. The location of the research are in the world scale

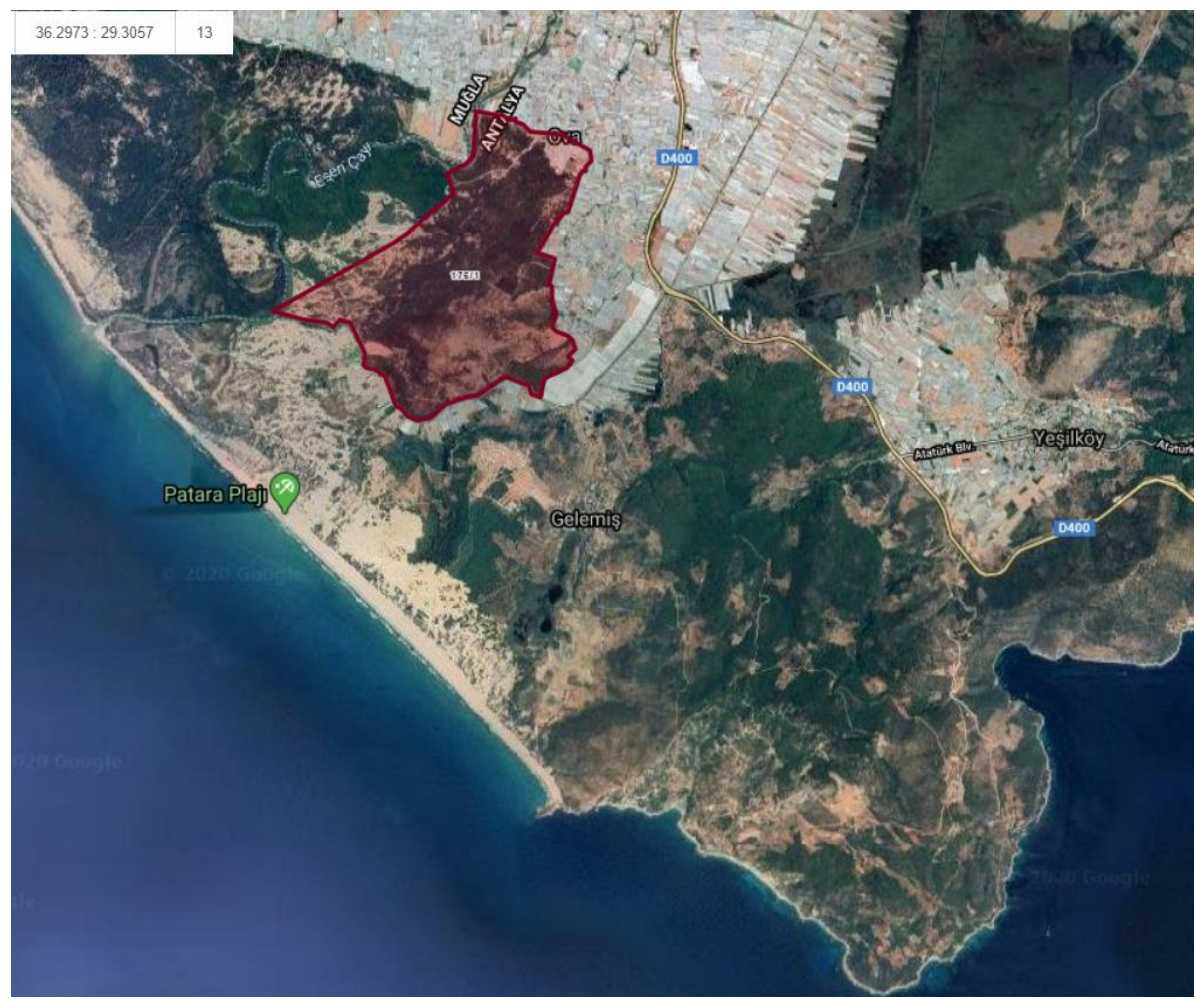

Figure 2. The parcel location of the research area (TKGM 2020) 


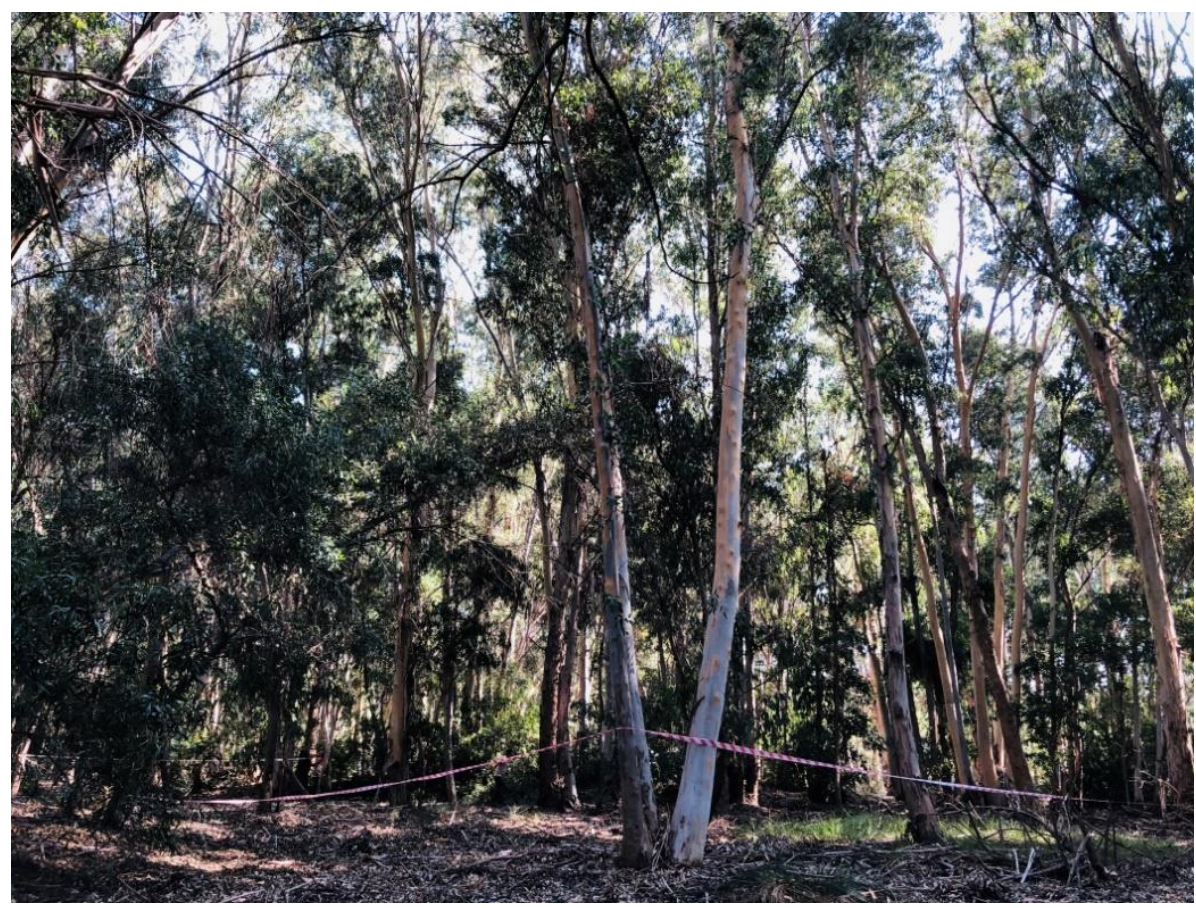

Figure 3. General view of the research area

\subsection{Method}

The research was conducted in 4 compartments (compartments noumbered 222, 226, 278 and 280) in the sand-dune afforestation in Patara. From each compartment, 30 of $20 \times 20 \mathrm{~m}$ sized sampling areas were selected according to the random sampling method, and the breast height diameter and height measurements as well as the seed counts were performed in the sampling areas. Also, the average growing stock per hectare was calculated by utilizing the average diameter and height values obtained. One-way analysis of variance and Duncan test were used in the statistical analysis of the data. All statistical analyses were carried out in SPSS statistical package program.

\section{Results and discussion}

\subsection{Diameter growth}

The results of the variance analysis and Duncan test applied to the diameter measurements made in the sampling areas selected from the 4 compartments constituting the research area are given in Table 1.

Table 1. The results of variance analysis and Duncan' test on average diameter growth

\begin{tabular}{cc}
\hline \multirow{2}{*}{ Compartments } & $P<0.05$ \\
\cline { 2 - 2 } 222 & Average Diameter $(\mathrm{cm})$ \\
226 & $33.6^{\mathrm{a}^{*}}$ \\
278 & $32.4^{\mathrm{a}}$ \\
280 & $43.2^{\mathrm{b}}$ \\
\hline *; the sam & $46.5^{\mathrm{c}}$ \\
\hline
\end{tabular}

\footnotetext{
*; the same letters are significantly different $(p<0.05)$.
}

As a result of variance analysis, it was found that there was a significant difference at $95 \%$ confidence level in terms of average diameter growth. As a result of Duncan test performed in order to determine homogeneous groups, 4 different groups were determined at 95\% confidence level (Table 1). Accordingly, while the best diameter growth in the eucalyptus used in the research area occurred in compartment no. 280, the lowest diameter growth was found as the average value in the sampling areas in compartment no. 226 (Table 1). These values determined at the end of the $80^{\text {th }}$ year were compared with other research results carried out in other afforestation areas under similar habitat conditions in the region. Accordingly, it was found that the average diameter of eucalyptus individuals in afforestation area in Adana-Akyatan varied between 31.6 and $44.7 \mathrm{~cm}$ at the end of $79^{\text {th }}$ year (Akca 2008). In accordance with these results, in terms of average diameter growth, it is possible to say that the eucalyptus individuals used in Patara sand-dune afforestation under the habitat conditions prevailing in the Mediterranean Region are at a sufficient level.

\subsection{Height growth}

Within the scope of the research, the average height growth values of eucalyptus individuals at the end of $80^{\text {th }}$ year were also identified in 4 compartments constituting the research area. Variance analysis and Duncan test results applied to these values are given in Table 2. 
Table 2. The results of variance analysis and Duncan' test on average height growth

\begin{tabular}{cc}
\hline Compartments & $P<0.05$ \\
\cline { 2 - 2 } & Average Height $(\mathrm{m})$ \\
\hline 222 & $19.8^{\mathrm{b}^{*}}$ \\
278 & $15.2^{\mathrm{a}}$ \\
280 & $21.3^{\mathrm{c}}$ \\
$24.6^{\mathrm{c}}$ \\
\hline *; the same letters are significantly different $(p<0.05)$.
\end{tabular}

According to data given in Table 2, as a result of variance analysis, a difference was found between the compartments at $95 \%$ confidence level in terms of average height growth. Within this scope, as a result of Duncan test conducted at the same confidence level, 3 different homogeneous groups were identified in terms of average height growth. Accordingly, the lowest average height growth was detected in the compartment no. 226 with a height growth of $15.2 \mathrm{~m}$ and the highest average height growth was detected in the compartment no. 280 with $24.6 \mathrm{~m}$ (Table 2). In the Adana-Akyatan afforestation, the average growth of eucalyptus individuals also varied between 18.4 and $26.3 \mathrm{~m}$ (Akca 2008). According to these results, in terms of average height growth, it can be said that the eucalyptus individuals used in Patara sand-dune afforestation under the habitat conditions prevailing in the Mediterranean Region are at a sufficient level.

\subsection{Average volume}

The average growing stock per hectare was calculated by using the findings obtained as a result of the measurements made in the sampling areas within the research content. The results of variance analysis and Duncan test applied to the average growing stock by compartments are given in Table 3.

Table 3. The results of variance analysis and Duncan' test of average volume

\begin{tabular}{cc}
\hline \multirow{2}{*}{ Compartments } & $P<0.05$ \\
\cline { 2 - 2 } & Average Volume $\left(\mathrm{m}^{3} / \mathrm{ha}\right)$ \\
222 & $9.164^{\mathrm{a}^{*}}$ \\
226 & $11.357^{\mathrm{b}}$ \\
280 & $12.445^{\mathrm{b}}$ \\
$13.758^{\mathrm{c}}$ \\
\hline *; the same letters are significantly different $(p<0.05)$.
\end{tabular}

*; the same letters are significantly different $(p<0.05)$.

When the results given in Table 3 were examined, it was found that there were statistical differences between the compartments at $95 \%$ confidence level. As a result of the Duncan test carried out within this scope, 3 different homogeneous groups were identified at a $95 \%$ confidence level. Accordingly, the lowest average volume was determined in compartment no. 222 with $9.164 \mathrm{~m}^{3} / \mathrm{ha}$, while the highest average volume was determined in compartment no. 280 with $13.758 \mathrm{~m}^{3} / \mathrm{ha}$ (Table 3). In a study conducted on the returns of eucalyptus afforestation, the average volume per hectare (bonitet II) was found to be varying between 8.27 and
$19.875 \mathrm{~m}^{3} /$ ha at a $3 \times 3 \mathrm{~m}$ planting interval (Birler et al. 1991). When these data are compared, it is possible to say that volume growth also shows a similar trend depending on diameter and height growth.

3.4. Survival

In the research, the survival percent, which was a significant criterion especially in determining adaptability, was also identified using the planting interval-distance in the sampling areas and in the plantation areas in the compartments. The results of the variance analysis and Duncan test applied to the average values of survival percent determined at the level of compartments are given in Table 4.

Table 4. The results of variance analysis and Duncan' test on the survival percent

\begin{tabular}{cc}
\hline \multirow{2}{*}{ Compartments } & $P<0.05$ \\
\cline { 2 - 2 } & Average Survival Percent $(\%)$ \\
\hline 222 & $71.8^{\mathrm{a}^{*}}$ \\
226 & $73.2^{\mathrm{a}}$ \\
280 & $84.5^{\mathrm{b}}$ \\
$86.3^{\mathrm{b}}$ \\
\hline *; the same letters are significantly different $(p<0.05)$.
\end{tabular}

When the variance analysis results were examined, it was found that there was a statistically significant difference between the compartments in terms of survival percent, which was the most important indicator of adaptability, at $95 \%$ confidence level. According to the Duncan test result performed at the same confidence level within this scope, 3 different homogeneous groups emerged (Table 4). Accordingly, while the highest survival percent was determined in compartment no. 280 with $86.3 \%$, the lowest survival percent was determined in compartment no. 222 with $71.8 \%$ (Table 4).

As in other variables, as a result of statistical analysis performed in terms of survival percent, the values in compartment no. 222 were found to be low. This situation is considered to have occurred due to the lack of sufficient soil depth in the said compartment as well as the lack of sufficient and favourable conditions in terms of organic matter, especially starting from the accumulation of plant litter. However, in the research studies conducted on different eucalyptus species and at the clonal level, it was found that in areas with similar habitat conditions as the research area, the survival percent decreased depending on the age but after the half of rotation period, it varied between 65 and $93 \%$ when the stand conditions are maintained (Avcioglu et al. 1994). In the light of these evaluations, it is possible to say that the species can adapt to Patara sand-dune area in Kas district of Antalya, where the afforestation take place.

As it is known, the rapid growth of the cultivated plants provides great advantages in many respects. As well as providing advantages against factors such as living cover in the plantation area, fast growing plants produce more raw materials. For this reason, there are very much studies about fast growing plants (Ozel and Ertekin 2010). 
The growth performances of plants arise as a result of the interaction between genetic structure and environmental conditions (Cetin et al. 2018 a,b; Hrivnák et al. 2017). For this reason, first of all the ecological conditions, namely the climatic and edaphic conditions in the environment, in which the plant is grown, play an extremely important role in plant growth (Yigit et al. 2019; Yucedag et al. 2019; Sevik et al. 2019a,b). Many factors such as precipitation, temperature, stress factors, light, air pollution and soil structure affect the morphological characteristics and growth of plants (Turkyilmaz et al. 2018a; Aricak et al. 2019).

In addition to this, genetic structure is one of the most critical factors affecting plant growth (Yigit et al. 2016). Morphological and physiological characteristics of plants are formed by the interaction of genetic structure and environmental factors. The reaction of the plant towards environmental factors is closely related to the genetic structure of the plant (Sevik et al. 2017). Since the plants of the same species have different genetic structures, they may react to the same growing conditions and stress conditions at different levels (Sevik et al. 2020a,b).

Studies conducted to date show that there may be significant differences in both growth performance and other morphological characteristics, even among individuals of the same provenance, as well as different provenances of the same species. For instance, it is found that different clones of the same species have different resistance to water and frost stress. Therefore, the components of these factors may affect the growth performance, namely the phenotypic properties of plants (Cetin et al. 2018a,b). For this reason, genetic improvement studies, in other words the identification of fast-growing provenances of a species, have been carried out for many years, especially on the principal forest tree species.

\section{Conclusions}

As a result of the variance analysis that applied to the raw data obtained as a result of the findings, measurements and counts made in the research area and that enabled comparison on the averages in terms of compartments, statistical differences at $95 \%$ confidence level were found between 4 compartments in terms of all variables. Within this context, as a result of Duncan test applied at $95 \%$ confidence level in order to determine homogeneous groups, it was determined that the best growth in all variables was observed in compartment no. 280 and the lowest growth and adaptation were observed in compartment no. 222. This situation is thought to be due to the soil structure and to the fact that compartment no. 280 has more sheltered physiographic conditions, especially since it is located on the inner coast comparing to the other compartments. In line with this information, according to the evaluations made in the Patara sanddune afforestation area at the end of the $81^{\text {st }}$ year, it can be said that the sand-dune stabilization works established in 1938 spending great time, effort and money are of great success.
More importantly, it is possible to say that the eucalyptus species used in these studies show good adaptability despite being an exotic species to the prevailing ecological conditions in the region. In addition to this, many settlements and agricultural lands located behind the coast are also preserved with these sand-dune stabilization and afforestation works. Besides, the fact that the said eucalyptus species is a fast growing species makes it possible to consider these afforestation works as industrial plantations. Based on the results obtained from this research, the sand-dune stabilization works and the successful afforestation works should be continued in the region using eucalyptus species and clones belonging to these species. Accordingly, studies should be conducted on determining genetic gain and adaptability of clones. Besides, afforestation works should be carried out both in the Mediterranean coastline and the zone behind the coast in order to gain new forest lands and to provide industrial wood raw material.

\section{References}

Akça A (2008). Plantasyon ormancılığında envanter metotları. I. Ulusal Okaliptüs Sempozyumu 15-17 Nisan, Tarsus.

Akça E, Yatkı S, Pekel M, Yılmaz S, Polat O, Polat S, Yılmaz E, Kapur S (2008) Akyatan kumulundaki (Kapıköy, Adana) ormancılık etkinliklerinin toprak kalitesine etkisi ve ekonomik getirisi. I. Ulusal Okaliptüs Sempozyumu 15-17 Nisan, Tarsus.

Anonim (2018). Antalya mıntıkası ağaçlandırma projeleri ve sonuçlarının değerlendirilmesi raporu, Antalya.

Anonim (2019). Türkiye ormanlarına ilişkin istatistiki bilgiler. OGM Raporu, Ankara.

Aricak B, Cetin M, Erdem R, Sevik H, Cometen H (2019). The change of some heavy metal concentrations in Scotch pine (Pinus sylvestris) depending on traffic density, organelle and washing. Applied Ecology and Environmental Research, 17(3):6723-6734.

Avcıoğlu E, Gürses MK, Gülbaba AG, Genç A, Özkurt N, Özkurt A (1994). Türkiye'de okaliptüslerin yetișebileceği bölgelerde tür ve orijin seçimi üzerine araştırmalar. Doğu Akdeniz Ormancılık Araştırma Enstitüsü, Teknik Bülten No:1, Tarsus.

Birler AS, Koçar S, Avcıŏlu E, Diner A, Gürses MK, Gülbaba AG (1991). Ökaliptüs ağaçlandırmalarında hacim ve kuru madde hasılatı. Kavak ve Hızlı Gelişen Tür Orman Ağaçları Araştırma Enstitüsü, Teknik Bülten No: 171, İzmit.

Boydak M (2008). Türkiye'de endüstriyel plantasyonlar ve önemi, I. Ulusal Ökaliptus Sempozyumu, 15-17 Nisan, Tarsus.

Cetin M, Sevik H, Yigit N (2018a). Climate type-related changes in the leaf micromorphological characters of certain landscape plants. Environmental monitoring and assessment, 190(7):404.

Cetin M, Sevik H, Yigit N, Ozel HB, Aricak B, Varol T (2018b). The variable of leaf micromorphogical characters on grown in distinct climate conditions in some landscape plants. Fresenius Environmental Bulletin, 27(5):3206-3211.

FAO (2019). World's Forest State, Rome, Italy.

Gadow K (2008). Eucalyptus grandis, tree growth and forest design, I. Ulusal Ökaliptus Sempozyumu, 15-17 Nisan, Tarsus.

Gülbaba AG (2008) Ökaliptüs (Eucalyptus camaldulensis Dehn.) klon denemesinde kalıtım dereceleri ve genetik kazancın belirlenmesi, I. Ulusal Ökaliptus Sempozyumu 15-17 Nisan, Tarsus.

Güngör F (2008). Tarsus Karabucak'ta Eucalyptus camaldulensis'in yetiştirilmesinde silvikültürel esaslar, gelişme ve dikim aralıklarının belirlenmesi üzerine incelemeler. I. Ulusal Ökaliptus Sempozyumu, 15-17 Nisan, Tarsus.

Ozel HB, Ertekin M (2010). Investigation of Relationship between some climate factors and height increment in Black Pine (Pinus nigra Arnold. ssp. pallasiana (Lamb.) Holmboe) and Scotch Pine (Pinus sylvestris L.) afforestations in the Devrek-Akçasu District. Ecological Life Sciences, 5(4):376-389. 
Sevik H, Cetin M, Kapucu O, Aricak B, Canturk U (2017). Effects of light on morphologic and stomatal characteristics of Turkish Fir needles (Abies nordmanniana subsp. Bornmulleriana Mattf.). Fresenius Environmental Bulletin, 26(11):6579-6587.

Sevik H, Cetin M, Ozel HB, Akarsu H, Cetin IZ (2020). Analyzing of usability of tree-rings as biomonitors for monitoring heavy metal accumulation in the atmosphere in urban area: a case study of cedar tree (Cedrus sp.). Environmental Monitoring and Assessment, 192(1):23.

Sevik H, Cetin M, Ozel HB, Ozel S, Cetin IZ (2020). Changes in heavy metal accumulation in some edible landscape plants depending on traffic density. Environmental Monitoring and Assessment, 192(2):78.

Sevik H, Cetin M, Ozturk A, Ozel HB, Pinar B (2019b). Changes in Pb, $\mathrm{Cr}$ and $\mathrm{Cu}$ concentrations in some bioindicators depending on traffic density on the basis of species and organs. Applied Ecology and Environmental Research, 17(6):12843-12857.

Sevik H, Cetin M, Ozturk A, Yigit N, Karakus O (2019a). Changes in micromorphological characters of Platanus orientalis L. leaves in Turkey. Applied Ecology and Environmental Research, 17(3):5909-5921.
TKGM (2020). Parsel sorgulama, Tapu ve Kadastro Genel Müdürlüğü, Resmî web sitesi, https://parselsorgu.tkgm.gov.tr/\#ara/idari/204602/176/1/158280149 3556, Son Erişim Tarihi: 27.02.2021.

Turkyilmaz A, Sevik H, Cetin M (2018a). The use of perennial needles as bio-monitors for recently accumulated heavy metals. Landsc Ecol Eng. 14(1):115-120.

Yigit N, Cetin M, Ozturk A, Sevik H, Cetin S (2019) Varitation of stomatal characteristics in Broad leaved species based on habitat. Applied ecology and Environmental Research, 17(6):12859-12868.

Yigit N, Sevik H, Cetin M, Gul L (2016). Clonal variation in chemical wood characteristics in Hanönü (Kastamonu) Günlüburun Black pine (Pinus nigra Arnold. subsp. pallasiana (Lamb.) Holmboe) seed orchard. Journal of Sustainable Forestry, 35(7):515-526.

Yucedag C, Ozel HB, Cetin M, Sevik H (2019). Variability in morphological traits of seedlings from five Euonymus japonicus cultivars. Environmental Monitoring and Assessment. 191:285. 